\title{
Hubungan antara Kegiatan Usap Abur dengan Kemampuan Motorik Halus Anak Usia Dini
}

\section{Widi Nuryani}

Pendidikan Islam Anak Usia Dini, Universitas Islam Negeri Sunan Gunung Djati Bandung Jalan Soekarno Hatta Cimincrang Gedebage Bandung 406294

Email: widinuryani30@gmail.com

Naskah diterima: 13 Agustus 2019, direvisi: 17 September 2019, diterbitkan: 27 September 2019

\begin{abstract}
Abstrak
Penelitian ini bertujuan untuk mengetahui kegiatan usap abur di Kelompok B RA Al-Muhajir Panyileukan Bandung, kemampuan motorik halus anak usia dini di Kelompok B RA AlMuhajir Panyileukan Bandung, dan hubungan antara kegiatan usap abur dengan kemampuan motorik halus anak usia dini di Kelompok B RA Al-Muhajir Panyileukan Bandung. Penelitian ini menggunakan metode kuantitatif korelasional. Subyek penelitian ini adalah anak Kelompok B RA Al-Muhajir Panyileukan Bandung yang berjumlah 17 orang. Hasil analisis pada kegiatan usap abur diperoleh nilai rata-rata sebesar 85 dengan kategori sangat baik. Sedangkan, kemampuan motorik halus anak usia dini diperoleh nilai rata-rata sebesar 79 dengan kategori baik. Hubungan antara kegiatan usap abur dengan kemampuan motorik halus anak usia dini diperoleh koefisien korelasi melalui rumus Spearman Rank sebesar 0,885 termasuk pada kategori sangat kuat. Hasil uji signifikansi diperoleh $t_{\text {hitung }}=7,356>$ harga $t_{\text {tabel }}=2.131$. Artinya hipotesis nol ditolak dan hipotesis alternatif diterima. Dengan kata lain, kegiatan usap abur memiliki hubungan yang signifikan dengan kemampuan motorik halus anak usia dini di Kelompok B RA Al-Muhajir Panyileukan Bandung. Adapun kontribusi kegiatan usap abur terhadap kemampuan motorik halus anak usia dini sebesar 78,32\%. Hal ini menunjukkan terdapat 21,68\% faktor lain yang mempengaruhi kemampuan motorik halus anak usia dini.
\end{abstract}

Kata kunci: Kegiatan Usap Abur, Motorik Halus, Anak Usia dini.

\author{
Abstract \\ This study aims to determine abur swab activities in Group B $\mathrm{R} A$ Al-Mubajir Panyileukan Bandung, fine \\ motor skills of young children in Group B RA Al-Mubajir Panyileukan Bandung, and the relationship \\ between abur swab activities with the fine motor abilities of early childhood in Group B $\mathrm{R} A$ Al-Mubajir
}


Panyileukan Bandung. This study uses a correlational quantitative method. The subjects of this study were 17 children from Group B RA Al-Mubajir Panyileukan Bandung. The results of the analysis on abur swab activities obtained an average value of 85 with a very good category. Meanwhile, fine motor skills of early childhood obtained an average value of 79 with a good category. The relationship between abur swab activities with fine motor skills of early childhood obtained by the correlation coefficient through the Spearman Rank formula of 0.885 is included in the very strong category. Significance test results obtained $=7,356>$ price $=2,131$. This means that the null bypothesis is rejected and the alternative bypothesis is accepted. In other words, abur swab activities have a significant relationship with early motor fine motor skills in Group B RA Al-Mubajir Panyileukan Bandung. The contribution of abur swab activities on early motor skills of early childhood was $78.32 \%$. This shows there are $21.68 \%$ of other factors that affect the fine motor abilities of early childhood.

Keywords: Abur Wipe Activities, Fine Motor, Early Childhood.

\section{Pendahuluan}

Pendidikan anak usia dini merupakan suatu wadah yang paling pertama untuk mengembangkan potensi dasar yang dimiliki oleh anak. Potensi dasar ini merupakan fondasi bagi anak untuk dapat menempuh kehidupan selanjutnya dengan lebih baik dan tumbuh sebagai manusia dewasa seutuhnya. Dalam hal ini, peran pendidikan anak dalam pengembangan potensi dasar sangatlah penting. Upaya pengembangan potensi anak usia dini akan ditekankan pada prinsip bermain sambil belajar dan belajar seraya bermain. Perkembangan anak sejak usia dini memerlukan dorongan dan rangsangan sebagaimana pohon memerlukan air dan pupuk.

Anak usia dini sering disebut dengan istilah golden age atau usia emas dikarenakan pada rentang usia ini anak mengalami pertumbuhan dan perkembangan yang sangat pesat. Anak usia dini memiliki karakteristik yang khas baik secara fisik, sosial, emosi, kognitif, dan spiritual yang berhubungan erat satu sama lain. Masa usia dini merupakan masa paling penting untuk sepanjang hidupnya, sebab masa usia dini adalah masa pembentukan fondasi dan dasar kepribadian yang akan menentukan pengalaman anak selanjutnya (Hasnida, 2014: 1).

Kebutuhan bagi pertumbuhan dan perkembangan anak adalah bermain sambil belajar. Bermain merupakan bentuk pembelajaran yang paling efektif digunakan pada saat kegiatan belajar mengajar karena setiap anak memiliki kepribadian dengan gaya belajar yang berbeda. Ketika sedang bermain, anak-anak melakukan gerak tubuh secara aktif sehingga semua aspek perkembangan anak dapat meningkat, salah satunya yaitu perkembangan fisik motorik. 
Menurut Novia (dalam Descraprio, 2013: 42) semua gerakan yang dilakukan oleh manusia dalam kehidupan sehari-hari, seperti berjalan, berlari, memegang, menarik, mengulur, dan menendang, termasuk keterampilan yang dihasilkan dari pembelajaran motorik.

Motorik merupakan perkembangan pengendalian gerakan tubuh melalui kegiatan yang terkordinir antara susunan saraf otot, otak, dan spinal cord. Perkembangan motorik meliputi motorik kasar dan motorik halus. Motorik kasar adalah gerakan tubuh yang menggunakan otot-otot besar atau sebagian besar seluruh anggota tubuh yang terpengaruhi oleh kematangan anak itu sendiri, contoh kemampuan duduk, menendang, berlari, naik turun tangga, dan lain-lain. Sedangkan motorik halus adalah gerakan yang menggunakan otot-otot halus atau sebagian anggota tubuh tertentu yang dipengaruhi oleh kesempatan untuk belajar dan berlatih, misalnya kemampuan memindahkan dari tangan, mencoret-coret menggunting, meremas, menggambar, dan lain-lain (Hasnida, 2014: 52).

Menurut Mulyasa (2012: 24) usia dini merupakan masa kritis bagi perkembangan motorik, dan masa yang paling tepat untuk mengajarkan berbagai keterampilan motorik, seperti menggambar, melukis, berenang dan bermain bola. Pembelajaran motorik terutama motorik halus, membutuhkan bimbingan dan arahan untuk melatih keluwesan otot-otot jari tangan yang dimiliki anak, karena setiap anak mempunyai gaya belajar dan karakteristik yang berbeda-beda. Salah satu kegiatan yang dapat melatih motorik halus anak yaitu dengan kegiatan usap abur.

Menurut Pamadhi dan Sukardi dalam Martinasari, dkk. (2016: 4) usap abur merupakan pembinaan keterampilan menggambar yang ditujukan untuk mengembangkan rasa keindahan melalui sentuhan warna dan keartistikan bentuk. Teknik ini tepat digunakan untuk mengembangkan gerak motorik halus anak-anak, karena dalam teknik usap abur dibutuhkan ketelitian dan keuletan.

Berdasarkan hasil observasi yang peneliti lakukan di kelompok B RA Al-Muhajir Panyileukan Bandung, terdapat beberapa anak yang terampil dalam kegiatan usap abur diantaranya anak mampu memadukan warna dengan baik dan kemampuan anak dalam mengoleskan warna pada pola telah rapi, namun berbeda halnya dengan kemampuan motorik halus, anak masih kaku dalam menggerakkan jari-jemarinya, anak belum mampu menulis dengan rapi serta anak masih belum mampu mengkoordinasikan keseimbangan antara mata dan tangan karena perhatiannya teralihkan dengan hal lain.

Berdasarkan permasalahan-permasalahan di atas, peneliti memandang telah terjadi kesenjangan antara tingginya kegiatan usap abur anak kelompok B RA Al-Muhajir 
Panyileukan Bandung dengan rendahnya kemampuan motorik halus. Berangkat dari kesenjangan tersebut peneliti tertarik mengadakan penelitian yang dirumuskan ke dalam judul "Hubungan antara Kegiatan Usap Abur dengan Kemampuan Motorik Halus Anak Usia Dini” (Penelitian di Kelompok B RA Al-Muhajir Panyileukan Bandung).

Tujuan dari penelitian ini adalah untuk mengetahui kegiatan usap abur di Kelompok B RA Al-Muhajir Panyileukan Bandung, kemampuan motorik halus anak usia dini di Kelompok B RA Al-Muhajir Panyileukan Bandung, dan hubungan antara kegiatan usap abur dengan kemampuan motorik halus anak usia dini di Kelompok B RA Al-Muhajir Panyileukan Bandung.

\section{Metodologi}

Metode penelitian yang digunakan dalam penelitian ini meliputi data kualitatif dan kuantitatif. Data kualitatif yaitu data yang diperoleh dari hasil observasi dan dokumentasi. Sementara itu, data kuantitatif adalah data yang dilakukan melalui penilaian dengan pedoman obervasi yang kemudian diolah secara statistik. Data-data dikumpulkan dengan bantuan instrumen khusus yang dirancang untuk menilai perilaku-perilaku, sedangkan informasiinformasi dianalisis dengan menggunakan prosedur-prosedur statistik dan pengujian hipotesis (Creswell, 2014: 27).

Sumber data yang dimaksud dalam penelitian ini adalah subjek dari mana data diperoleh dan pengangkatan sumber datanya bersumber dari populasi dan sampel (Suharsimi Arikunto, 2013: 172). Menurut S. Margono (2005), populasi adalah seluruh data yang menjadi perhatian dalam suatu ruang lingkup dan waktu yang ditentukan. Jadi, populasi berhubungan dengan data, bukan manusianya. Jika manusia memberikan suatu data, maka banyaknya atau ukuran populasi akan sama banyaknya dengan ukuran manusia. Adapun populasi dalam penelitian ini adalah seluruh siswa kelompok B RA Al-Muhajir yang berjumlah 17 anak, laki-laki 12 orang dan perempuan 5 orang.

Menurut Sugiyono (2008: 116) sampel adalah sebagian dari jumlah karakteristik yang dimiliki oleh populasi tersebut. Jadi sampel adalah kelompok kecil (bagian) dari populasi yang diambil dan dapat mewakili karakteristik populasinya. Adapun sampel dalam penelitian ini menggunakan sampel jenuh, teknik penentuan sampel jenuh ini semua anggota populasi digunakan sebagai responden penelitian yaitu 17 siswa kelompok B RA Al-Muhajir Panyileukan Bandung. 
Teknik analisis yang digunakan dalam penelitian ini adalah teknik analisis menggunakan rumus statistik, dengan rumus korelasi sederhana. Menurut Sudjana (2009: 15) tahapan analisis korelasi, yaitu: (1) uji validitas, (2) uji reliabilitas, (3) analisis parsial, (4) uji normalitas, (5) uji linearitas regresi, (6) uji korelasi, (7) uji hipotesis. Pertama uji validitas, sebagaimana diketahui validitas ini dilakukan untuk menguji suatu instrumen valid atau tidak. Prosedur pengujian nya dengan membandingkan harga $r_{\text {hitung }}$ dengan $r_{\text {tabel. }}$. Jika $r_{\text {hitung }} \geq r_{\text {tabel }}$, maka instrumen valid, jika $r_{\text {hitung }}<r_{\text {tabel, }}$, maka instrumen tidak valid.

Kedua uji reliabilitas adalah suatu tes, dapat dikatakan memiliki taraf kepercayaan atau daya keajegan yang tinggi apabila tes tersebut dapat memberikan hasil yang sama, bila tes tersebut diberikan kepada siswa yang sama pada waktu yang berbeda (Hayati, 2013: 121). Menginterpretasi koefisien reliabilitas ini yaitu dengan ketentuan: Jika $r_{11} \geq 0,70$ berarti instrumen tersebut reliabel, dan jika $r_{11}<0,70$ berarti instrumen tersebut un-reliable (tidak reliabel). Ketiga Analisis Parsial ini dimaksudkan untuk menguji dan menghitung skor ratarata indikator vaiabel $\mathrm{X}$ dan variabel $\mathrm{Y}$, dengan rumus: untuk indikator variabel $\mathrm{X}$ adalah $\mathrm{X}$ $=\frac{\Sigma f \pi}{N}$ dan untuk indikator variabel $Y$ adalah $Y=\frac{\Sigma f \pi}{N}$.

Keempat uji normalitas ini bertujuan untuk melihat apakah data distribusi normal atau tidak. Menginterpretasikan data dengan membandingkan $\chi^{2}$ hitung dengan $\chi^{2}$ tabel, dengan kriteria: Jika $\chi^{2}$ bitung lebih besar dari $\chi^{2}$ tabel ( $\chi^{2}$ bitung $>\chi^{2}$ tabel), maka data diinterpretasikan tidak normal, dan jika $\chi^{2}$ bitung lebih kecil atau sama dengan $\chi^{2}$ tabel ( $\chi^{2}$ bitung $\leq \chi^{2}$ tabel), maka data diinterpretasikan normal. Kelima uji linearitas regresi dilakukan untuk mengetahui data yang dihubungkan berbentuk regresi garis linear atau tidak. Menginterpretasikan linearitas regresi dengan membandingkan nilai Fhitung dengan nilai Ftabel dengan ketentuan: Jika $F_{\text {hitung }} \leq \mathrm{F}_{\text {tabel }}$, berarti regresi $Y$ terhadap $X$, linier; dan jika $F_{\text {hitung }}>F_{\text {tabel }}$, berarti regresi Y terhadap X, tidak linier.

Keenam Menurut Tuti Hayati (2013: 91) korelasi dapat didefinisikan sebagai hubungan timbal balik antara dua hal atau lebih, atau keadaan saling ketergantungan dua variabel yang dihitung secara kuantitas. Apabila diperoleh kedua variabel berdistribusi normal dan regresinya linear, maka rumus korelasi yang digunakan adalah rumus korelasi Product Moment. Sedangkan, jika salah satu variabelnya tidak normal dan regresinya tidak linier, maka menggunakan korelasi Spearman Rank. Ketujuh uji hipotesis ini bertujuan untuk mencari makna hubungan variabel X (Kegiatan usap abur) terhadap variabel Y (Kemampuan motorik halus anak usia dini). Menginterpretasikan atau menguji signifikansi koefisien korelasi dengan 
ketentuan: Jika $t_{\text {hitung }} \geq t_{\text {tabel }}$ maka Ho (Hipotesis nol) ditolak dan Ha (Hipotesis alternatif) diterima. Dan jika $t_{\text {hitung }}<t_{\text {tabel }}$ maka Ho (Hipotesis nol) diterima dan Ha (Hipotesis alternatif) ditolak.

\section{Hasil dan Diskusi}

Berdasarkan hasil analisis yang dilakukan dengan pengambilan data melalui observasi kepada 17 siswa/siswi di Kelompok B RA Al-Muhajir Panyileukan Bandung mengenai kegiatan usap abur diperoleh nilai rata-rata sebesar 85. Angka tersebut berada pada interval 80-100 dengan kategori sangat baik. Sedangkan kemampuan motorik halus anak usia dini di Kelompok B RA Al-Muhajir Panyileukan Bandung diperoleh nilai rata-rata sebesar 79. Angka tersebut berada pada interval $70-79$ artinya berkualifikasi baik.

Untuk mengetahui Hubungan antara Kegiatan Usap Abur dengan Kemampuan Motorik Halus Anak Usia Dini, terlebih dahulu dilakukan uji persyaratan yaitu uji normalitas dan uji regresi linier. Dalam menghitung uji normalitas dilakukan dengan perhitungan chi kuadrat $\left(\chi^{2}\right)$. Untuk variabel X (Kegiatan Usap Abur) diperoleh mean $=85,88$; dan standar deviasi $=4,59$, nilai chi kuadrat $\left(\chi^{2}\right)$ hitung $=2,916$; dan chi kuadrat $\left(\chi^{2}\right)$ tabel $=7,815$ dengan $\mathrm{db}=3$ pada taraf signifikansi 5\%. Karena $\left(\chi^{2}\right)$ hitung $=2,916<\left(\chi^{2}\right)$ tabel $=7,815$, maka data tentang kegiatan usap abur berdistribusi normal. Kemudian untuk uji normalitas variabel $Y$ (Kemampuan Motorik Halus Anak Usia Dini) diperoleh mean = 79,76; dan standar deviasi $=6,80$, nilai chi kuadrat $\left(\chi^{2}\right)$ hitung $=9,600$; dan chi kuadrat $\left(\chi^{2}\right)$ tabel $=9,488$ dengan $\mathrm{db}=$ 4 pada taraf signifikansi 5\%. Karena $\left(\chi^{2}\right)$ hitung $=9,600>\left(\chi^{2}\right)$ tabel $=9,488$, maka data tentang kemampuan motorik halus anak usia dini berdistribusi tidak normal.

Berdasarkan hasil perhitungan korelasi dengan rumus Spearman Rank diperoleh koefisien korelasi antara kegiatan usap abur dengan kemampuan motorik halus anak usia dini sebesar 0,885 angka tersebut berada pada interval 0,800-1,000 dengan kategori sangat kuat. Hal ini ditunjukkan pula oleh hasil pengujian hipotesis diperoleh harga $t_{\text {hitung yaitu }}$,356 dan $t_{\text {tabel }}$ dengan $d b=15$ pada taraf signifikansi 5\% sebesar 2,131. Oleh karena itu, dapat diambil kesimpulan bahwa $t_{\text {hitung }}=0,7356>t_{\text {tabel }}=2,131$ maka dapat diinterpretasikan Ho (Hipotesis nol) ditolak dan Ha (Hipotesis alternatif) diterima. Dengan kata lain kegiatan usap abur memiliki hubungan positif yang signifikan dengan kemampuan motorik halus anak usia dini di Kelompok B RA Al-Muhajir Panyileukan Bandung. 
Selain itu hasil perhitungan koefisien determinasi, dapat disimpulkan bahwa kegiatan usap abur memberi kontribusi sebesar 78,32\% terhadap kemampuan motorik halus anak usia dini di Kelompok B RA Al-Muhajir Panyileukan Bandung. Sedangkan 21,68\% kemampuan motorik halus anak usia dini dipengaruhi faktor lain.

Hubungan kegiatan usap abur dengan kemampuan motorik halus anak usia dini di Kelompok B RA Al-Muhajir Panyileukan Bandung termasuk ke dalam kategori sangat kuat, karena berdasarkan penelitian kegiatan usap abur sangat digemari oleh anak-anak. Apalagi pada saat mengisi bidang gambar yang harus diberi warna/mengoleskan warna pada pola. Anak dapat memilih berbagai warna yang anak sukai untuk mengoleskan pada pola yang telah ditentukan. Hal tersebut sesuai dengan pendapat Sumanto (2005: 65) bahwa kreativitas yang dikembangkan pada kegiatan mewarnai bagi anak adalah adanya kebebasan untuk memilih dan mengkombinasikan unsur warna pada obyek yang diwarnainya sesuai dengan keinginan anak.

Kemampuan motorik halus anak senantiasa akan terlatih dengan baik, apabila dilakukan secara bertahap dan berulang-ulang sesuai kemampuan anak, stimulasi yang diberikan sesuai usia dan taraf pertumbuhan dan perkembangan anak, dilakukan dengan kegiatan menarik dan menyenangkan, serta memberi motivasi terhadap anak. Bagi anak usia prasekolah, gerakan-gerakan motorik halus tidak sekedar penting untuk mengembangkan kemampuan motorik halus anak usia dini, melainkan juga berpengaruh terhadap pertumbuhan rasa percaya diri bahkan perkembangan kognisi.

Bagi Sumantri (2005: 121) kemampuan motorik halus anak dapat berkembang meskipun tanpa stimulasi, tetapi kemampuan yang dicapai tidak akan maksimal atau hanya mencapai batas minimal yang ada. Stimulasi yang dapat diberikan untuk anak usia 5-6 tahun dengan tujuan mengembangkan kemampuan motorik halus dapat dilakukan dengan beberapa kegiatan yang membutuhkan ketelitian, kecermatan serta kesabaran untuk melakukannya. Kemampuan motorik halus yang dimiliki setiap anak berbeda, ada yang lambat ada pula yang sesuai dengan perkembangan, tergantung pada kematangan anak. Namun sebaiknya selaku pendidik atau orang tua hendaknya mengetahui permasalahan dan memberikan solusi bagaimana motorik halus anak berkembang sesuai dengan tahapannya.

\section{Penutup}


Berdasarkan hasil penelitian yang dilakukan di Kelompok B RA Al-Muhajir Panyileukan Bandung mengenai hubungan antara kegiatan usap abur dengan kemampuan motorik halus anak usia dini, maka dapat disimpulkan bahwa kegiatan usap abur diperoleh nilai rata-rata sebesar 85. Angka tersebut berada pada interval 80 - 100 dengan kategori sangat baik. Artinya kegiatan usap abur di Kelompok B RA Al-Muhajir Panyileukan Bandung berkualifikasi sangat baik. Sedangkan kemampuan motorik halus anak usia dini diperoleh nilai rata-rata sebesar 79. Angka tersebut berada pada interval 70 - 79 dengan kategori baik. Artinya kemampuan motorik halus anak usia dini di Kelompok B RA Al-Muhajir Panyileukan Bandung berkualifikasi baik.

Hasil pengujian data statistik menujukkan bahwa hubungan antara kegiatan usap abur dengan kemampuan motorik halus anak usia dini diperoleh angka koefisien korelasi sebesar 0,885. Angka koefisien korelasi ini termasuk pada kategori sangat kuat karena berada pada interval 0,800-1,000. Hasil uji signifikansi diperoleh harga $t_{\text {hitung }}=7,356$ lebih besar dari harga $\mathrm{t}_{\text {tabel }}=2$,131. Artinya Ho (Hipotesis nol) ditolak dan $\mathrm{Ha}$ (Hipotesis alternatif) diterima. Dengan kata lain kegiatan usap abur memiliki hubungan positif yang signifikan dengan kemampuan motorik halus anak usia dini di Kelompok B RA Al-Muhajir Panyileukan Bandung. Adapun besar kontribusi/pengaruh kegiatan usap abur (Variabel X) terhadap kemampuan motorik halus anak usia dini (Variabel Y) sebesar 78,32\%. Hal ini menunjukkan terdapat 21,68\% faktor lain yang mempengaruhi kemampuan motorik halus anak usia dini.

\section{Daftar Pustaka}

Arikunto, S. (2013). Prosedur Penelitian Suatu Pendekatan Praktik. Jakarta: Rineka Cipta.

Creswell. (2014). Research Desain: Pendekatan Kualitatif, Kuantittaif, dan Mixed. Yogyakarta: Pustaka Pelajar.

Hasnida. (2014). Analisis Kebutuban Anak Usia Dini. Jakarta: PT. Luxima Metro Media.

Hayati, T. (2013). Pengantar Statistika Pendidikan. Bandung: CV. Insan Mandiri.

Margono. (2005). Metodologi Penelitian Pendidikan. Jakarta: PT. Rineka Cipta.

Martinasari, dkk. (2016). Penerapan Metode Pemberian Tugas melalui Kegiatan Usap Abur untuk Meningkatkan Keterampilan Motorik Halus Pada Anak. Jurnal Volume 4 Nomor 2. Singaraja: Universitas Pendidikan Ganesha.

Mulyasa. (2012). Managemen Paud. Bandung: PT Remaja Rosdakarya.

Sudjana. (2009). Metode Statistika. Bandung Tarsito

Sugiyono. (2008). Metode Penelitian (Pendekatan Kuantitatif. Kualitatif, dan R\&D). Bandung: Alfabeta. 
Sumanto. (2005). Pengembangan Kreativitas Seni Rupa Anak TK. Jakarta: Departemen Pendidikan Nasional.

Sumantri. (2005). Model Pengembangan Keterampilan Motorik Anak Usia Dini. Jakarta: Departemen Pendidikan Nasional.

Valiatin, N. (2017). Peningkatan Kemampuan Motorik Halus Anak Kelompok B2 melalui Kegiatan Melukis dengan Teknik Usap Abur. Skripsi. Universitas Jember.

\section{Biodata Penulis}

Widi Nuryani, lahir di Garut pada tanggal 30 Maret 1997 terlahir dari pasangan Bapak Yadin Supriadin dan Ibu E. Sumyati, merupakan anak ke dua dari empat bersaudara. Bertempat tinggal di Kp. Cibacang, RT/RW 03/09, Ds. Majasari, Kec. Cibiuk, Kab Garut 44193. Menyelesaikan Pendidikan Program Sarjan Pendidikan Islam Anak Usia Dini di Fakultas Tarabiyah dan Keguruan UIN Sunan Gunung Djati Bandung pada tahun 2019. 